\title{
Growth and mineral composition of Jatropha curcas L. under phosphate fertilization and soil compaction
}

Tiago Mendes Rodrigues ${ }^{1}$, Dilermando Dourado Pacheco ${ }^{1}$, Tatiane Carla Silva ${ }^{2}$, Jair Henrique de Castro ${ }^{1}$, Gildarley Costa da Cruz ${ }^{1}$, Maurício Ferreira Lopes ${ }^{3}$, Rafael Montanari ${ }^{2}$

${ }^{1}$ Instituto Federal Norte de Minas Gerais - IFNMG, Januária, MG. ${ }^{2}$ Universidade Estadual Paulista - UNESP, Ilha Solteira, SP. ${ }^{3}$ Companhia Nacional de Abastecimento - Conab. E-mail: tcs.agronomia@gmail.com

\begin{abstract}
The present work aimed to quantify the growth of young physic nut plants submitted to variations in phosphorus (P) and specific masses of a Red Yellow Latosol soil. Previously, a soil sample was collected in the 20 to $40 \mathrm{~cm}$ layer, making sure in the laboratory the low availability of $P-1.4 \mathrm{mg} \mathrm{dm}^{-3}$ - to apply the treatments of interest. Doses of 0,106 and $318 \mathrm{mg} \mathrm{dm}^{-3}$ of $P$ were applied, using the simple superphosphate source; and the soils were compacted until reaching specific soil masses equal to 1.53; 1.72 and $1.91 \mathrm{~kg} \mathrm{dm}^{-3}$, in a complete factorial scheme, totaling nine treatments. The cultivation was carried out in pots and the dry biomass of the aerial part of the physic nut and its parts fractionated in the stem, leaves adhered to the stem and senescent leaves were determined. The contents of $\mathrm{P}, \mathrm{K}, \mathrm{Ca}, \mathrm{Mg}, \mathrm{Cu}, \mathrm{Fe}$, $\mathrm{Mn}$ and $\mathrm{Zn}$ were determined, and from the dry mass accumulation data, the contents of these minerals in the plants were quantified. The statistical analysis of the data consisted of analysis of variance, Tukey average test and regression analysis. In general, the mineral composition characteristics of the plants showed a more pronounced response to phosphate fertilization compared to the tested physical compression. The maximum estimated mineral content in physic nut plants was $51.78 \mathrm{mg}$ of $\mathrm{P} ; 463.37 \mathrm{mg}$ of K; $201.84 \mathrm{mg}$ of Ca; $124.18 \mathrm{mg}$ of $\mathrm{Mg} ; 76.17 \mu \mathrm{g}$ of $\mathrm{Cu} ; 4,254.07 \mu \mathrm{g}$ of Fe; $18,787.15 \mu \mathrm{g}$ of $\mathrm{Mn}$ and 769,97 $\mu \mathrm{g}$ of $\mathrm{Zn}$.
\end{abstract}

Keywords: Jatropha curcas L.; phosphate fertilization; soil compressibility.

\section{Composição mineral da planta de pinhão-manso em resposta à adubação fosfatada e compactação do solo}

\section{Resumo}

O presente trabalho objetivou quantificar o crescimento de plantas jovens de pinhão-manso submetidas a variações de doses de fósforo $(P)$ e de massas específicas de um solo Latossolo Vermelho Amarelo. Previamente, foi coletada uma amostra de solo na camada de 20 a $40 \mathrm{~cm}$, certificando-se em laboratório, a baixa disponibilidade de $P-1,4 \mathrm{mg} \mathrm{dm}^{-3}-$ a fim de se aplicar os tratamentos de interesse. Foram aplicadas doses de 0,106 e $318 \mathrm{mg} \mathrm{dm}^{-3}$ de $P$, utilizando a fonte superfosfato simples; e os solos foram compactados até atingirem massas específicas de solo iguais a 1,53; 1,72 e 1,91 $\mathrm{kg} \mathrm{dm}^{-3}$, em esquema fatorial completo, totalizando nove tratamentos. $O$ cultivo foi em vasos e foram determinadas a biomassa seca da parte aérea do pinhão-manso e das suas partes fracionadas em caule, folhas aderidas ao caule e folhas senescentes. Foram determinados os teores de $\mathrm{P}, \mathrm{K}, \mathrm{Ca}, \mathrm{Mg}, \mathrm{Cu}, \mathrm{Fe}, \mathrm{Mn}$ e $\mathrm{Zn}$, e a partir dos dados de acúmulo de massa seca se quantificou os conteúdos desses minerais nas plantas. A análise estatística dos dados consistiu em análise de variância, teste de média Tukey e análise de regressão. De modo geral, as características de composição mineral das plantas apresentaram resposta mais pronunciada à adubação fosfatada comparada à compressão física testada. Os máximos conteúdos de minerais estimados nas plantas de pinhão-manso foram de 51,78 mg de P; 463,37 mg de K; 201,84 mg de Ca; 124,18 mg de Mg; 76,17 $\mu \mathrm{g}$ de $\mathrm{Cu} ; 4.254,07 \mu \mathrm{g}$ de Fe; 18.787,15 $\mu \mathrm{g}$ de Mn e 769,97 $\mu \mathrm{g}$ de Zn.

Palavras-chave: Jatropha curcas L.; adubação fosfatada; compressibilidade de solo. 


\section{Introduction}

The physic nut (Jatropha curcas L.) increases the amount of oil in its seeds, thus becoming a potential raw material to produce biodiesel (SOUZA et al., 2010). It is a very rustic plant that adapts to different climates and soils, also giving tolerance to drought. Benefiting from attributes, its cultivation is a planting alternative for the small and medium rural producer in the north of Minas Gerais (CASTRO et al., 2021).

Jatropha propagation occurs through seeds, cuttings from adult tree pruning, in vitro micropropagation or tissue culture. According to Saturnino et al. (2005), plants originating from seeds bloom nine months after sowing, while those multiplied by cuttings bloom six months after planting. They can be planted directly in the field or seedlings can be generated for later planting, which is safer (PAULINO et al., 2011). Cuttings can be rooted in plastic bags with substrates. Regardless of the propagation method, the parent plants - derived from the source of seeds or cuttings - must have a known origin, free of diseases, quite productive and with a high oil content in their seeds.

Despite being considered a rustic plant, adapted to marginal edaphoclimatic conditions, physic nut requires the application of cultivation technologies (fertilization, pest and disease control, management practices, etc.) to present fruit production levels (LAVIOLA; DIAS, 2008).

The soils in the north of Minas Gerais are deficient in phosphorus $(\mathrm{P})$, either due to the poverty in the soils or the richness of these in $\mathrm{Fe}$ and $\mathrm{Al}$ sesquioxides, or both conditions, such as those inherent to the various local oxisol soils (SOUZA et al., 1999). The low availability of $\mathrm{P}$ is aggravated by the conventional soil tillage system commonly adopted in the region - successive plowing and harrowing - as which elevates a specific soil mass, causing its compaction. Specifically for the availability of $P$, compaction is problematic because it increases the tortuosity of the path from $P$ to the absorbent root, and with this a greater percentage of the element is fixed by the soil at the cost of being transported to the roots.

Compaction and $\mathrm{P}$ deficiency have an impact on the productivity of most crops, as changes in the physiological nature of this joint action cause a mineral composition of the plant to differ from a plant considered to be optimal, but this has not yet been reported for physic nut (VILLAR, 2007).

In this sense, the present work aimed to determine the joint effect of soil specific mass and $P$ doses on a mineral composition of physic nut plants in early growth stages.

\section{Material and methods}

The experiment was carried out in a greenhouse located at the Federal Institute of Northern Minas Gerais (IFNMG), "Januária campus" with the following geographical coordinates: Latitude: $15^{\circ} 26^{\prime} \mathrm{S}$, Longitude: $44^{\circ}$ $22^{\circ} \mathrm{W}$, and altitude of $474 \mathrm{~m}$. The region has an average annual temperature of $24.4 C$, an average relative humidity of $60 \%$ and an average annual rainfall of $814 \mathrm{~mm}$ (OLIVEIRA et al., 2020). The dimensions of the greenhouse were $3.00 \mathrm{~m}$ of "ceiling height"; $4.00 \mathrm{~m}$ high in the central span; $25 \mathrm{~m}$ long and $6 \mathrm{~m}$ wide. The upper cover consisted of a $60 \%$ mesh shade and on the side, there was a galvanized mesh. The benches where the experimental units were placed were at a height of $0.6 \mathrm{~m}$ from the ground, being made up of slatted floors, covering a width of $1.3 \mathrm{~m}$.

For the application of the treatments, a soil sample was used, Oxisol Red Yellow, collected in the layer of 20-40 cm deep, in an area traditionally cultivated with sorghum in a conventional soil preparation system with harrowing, taking care to use a soil with low availability of $P\left(1.4 \mathrm{mg} \mathrm{dm}^{-3}\right.$ of $\left.\mathrm{P}\right)$. The initial specific mass of soil, determined by the volumetric ring method (EMBRAPA, 1997), was $1.77 \mathrm{mg} \mathrm{dm}^{-3}$. The other physical-chemical characteristics of the soil are listed in table1.

Table 1. Physico-chemical characterization of soil sample collected in the $20-40 \mathrm{~cm}$ deep layer.

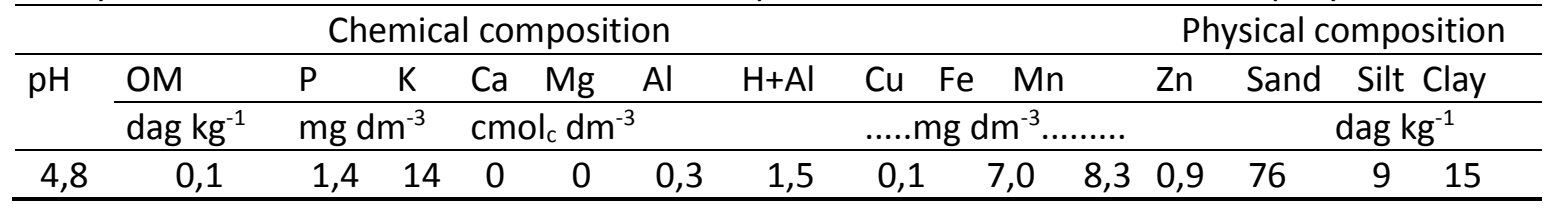


The nine treatments were defined by the combination of soil compressibility factors and $\mathrm{P}$ doses, each with three levels, distributed in a complete factorial and in a randomized block design, with three the number of repetitions, totaling 27 experimental plots. To apply these treatments, the soil was initially dried in the shade and then sieved in a $4 \mathrm{~mm}$ mesh sieve. Then, nine measurements were made with 9.062, 9.810 and $10.560 \mathrm{~kg}$ of soil. Soil incubation was carried out, applying to each of the previous measures the amounts of $3.84 \mathrm{~g}$ of limestone (25\% Si; $54 \% \mathrm{Ca} ; 12 \% \mathrm{Mg} ; 98 \%$ reactivity and $113 \%$ PRNT); $3.142 \mathrm{~g}$ of ammonium sulfate; 1.958 $\mathrm{g}$ of potassium chloride; $5.584 \mathrm{~g}$ of magnesium sulfate; $0.0370 \mathrm{~g}$ of boric acid; $0.157 \mathrm{~g}$ of zinc sulfate; $0.003 \mathrm{~g}$ of ammonium molybdate. The applied doses of $\mathrm{P}$ were $0 ; 7.994$ and $23.983 \mathrm{~g}$ of simple superphosphate (18\% P2O5). The amounts of water used for incubation were 2.809, 3.040 and $3.276 \mathrm{~mL}$, applied to the 9.062 masses, respectively: 9,810 and $10,560 \mathrm{~kg}$ of soil, providing moisture equal to $31 \%$. The incubation process lasted 15 days, to stabilize the chemical reactions resulting from the application of the fertilizers.

For application of the experimental units, PVC pots with an internal diameter of 19.4 $\mathrm{cm}$ and a height of $23.5 \mathrm{~cm}$ were used, sealing the base of the vase with pine wood $(2.5 \mathrm{~cm}$ thick), which was waterproofed with selfadhesive plastic. When disregarding $1 \mathrm{~cm}$ of upper edge, each pot had a useful volume equal to $5.912 \mathrm{dm}^{3}$, which were filled with the soil mass corresponding to each treatment referring to the nine possible combinations of 2 factors: specific soil mass and doses of $P$. On the lower side of the vessels, four holes were made, positioned in the shape of a cross, where micro tubes of $5 \mathrm{~mm}$ in diameter were inserted, which functioned as drains.
The soil samples, after the incubation phase, were placed in the pots, divided into three layers of equal height. Physical compressions were applied to the lower two layers to allow specific masses of soil equal to $1.53,1.72$ and $1.91 \mathrm{~kg} \mathrm{dm}^{-3}$, while in the upper layer the specific mass of $1.53 \mathrm{~kg} \mathrm{dm}^{-3}$ of soil common to all treatments was used, to allow the formation and initial growth of the root system of the plant. For purposes of physical compression, a mallet-type socket was used, with a mass of $1.030 \mathrm{~kg}$ and an exposure surface equal to $4275 \mathrm{~mm} 2(71.54 \mathrm{x}$ $59.78 \mathrm{~mm}$ ). For this purpose, the humidity of the soil samples was restored equal to that of the beginning of the incubation process.

The nine treatments were used: 0, 106 and $318 \mathrm{mg} \mathrm{dm}^{-3}$ of $P$ factorially combined to the specific masses of $1.53,1.72$ and $1.91 \mathrm{~kg} \mathrm{dm}^{-3}$ of soil - considered one pot per plot. On the benches, the pots were placed in three rows, 20 $\mathrm{cm}$ away from the central row in relation to the ends, obeying the same spacing between pots within the row. Three physic nut seeds were sown per pot, at a depth of $3 \mathrm{~cm}$. The seeds were extracted from a matrix plant belonging to a Jatropha demonstration unit located at IFNMG, "Januária" campus. The plants emerged seven days after sowing (DAS) and thinning was carried out at 15 DAS, allowing the growth of the most vigorous plant in each pot.

The cultural treatments consisted of manual collection of pests, a rare occurrence, scarification of soil at 30 DAS, to prevent algae growth and to facilitate the infiltration of water, and periodic irrigation, according to water needs. of the plants, using rainwater stored in a 2,000 L water tank (Table 2), being classified as low risk of salinization.

Table 2. Chemical characterization of the water used for irrigation of the experiment.

\begin{tabular}{|c|c|c|c|c|c|c|c|c|}
\hline \multicolumn{9}{|c|}{ Chemical composition } \\
\hline \multirow[t]{2}{*}{$\mathrm{pH}$} & $\mathrm{CE}$ & $\mathrm{Ca}$ & $\mathrm{Mg}$ & $\mathrm{K}$ & $\mathrm{Na}$ & $\mathrm{CO}_{3}^{2-}$ & $\mathrm{HCO}_{3}^{-}$ & $\mathrm{Cl}^{-}$ \\
\hline &.$\mu \mathrm{m} \mathrm{cm}^{-1} 25 \stackrel{\circ}{ } \mathrm{C}$. & $\ldots \ldots \ldots$ & ......... & $\ldots \ldots . .$. & olc $d m$ & & & \\
\hline 6.9 & 29 & 0.07 & 0.00 & 0.04 & 0.08 & 0.00 & 0.04 & 1.20 \\
\hline
\end{tabular}

The experiment was collected at 123 DAS. The plants were divided into leaves adhered to the stem, senescent leaves (including those harvested during the experiment) and stem, quantifying, in an analytical balance, the biomass accumulated in each of these organs after they were dried in a ventilation oven. forced air to constant mass. Subsequently, said parts of the plants were ground in a Wiley mill of $\mathbf{3 0}$ meshes per inch and subjected to nitric-perchloric 
digestion, to quantify the contents of $\mathrm{K}, \mathrm{P}, \mathrm{Ca}$, $\mathrm{Mg}, \mathrm{S}, \mathrm{Cu}, \mathrm{Fe}, \mathrm{Mn}$ and $\mathrm{Zn}$, and sulfuric for determination of $\mathrm{N}$ by distillation-Kjeldahl titration following the methodologies described by (MALAVOLTA, 2006). From the mineral contents and the biomass accumulated in the aerial part, the chemical contents were quantified.

The data of dry mass, content and mineral content in the aerial part of physic nut were subjected to analysis of variance, considering as dependent variables the $\mathrm{P}$ doses, the specific masses of soil and the organ (stem, senescent leaves and live leaves). Then, the Tukey average test was performed, at the level of $5 \%$ probability, to determine the significant differences for each of these characteristics, depending on the organ studied. For regression analysis, the data were considered as variables dependent on $\mathrm{P}$ doses and specific soil masses.

\section{Results and discussion}

The dry mass of the aerial part of physic nut was significantly higher in the stem, compared to the amounts detected in live and senescent leaves (Table 3). Pacheco et al. (2006b) also found maximum accumulation of dry mass in the stem compared to the values found in petioles, limbs and physic nut roots, explaining this behavior because the stem is the structural organ of the plant and for constituting the main organ of this plant's organic reserve.

Mineral concentrations, in most situations, were lower in the stem (Table 3 ). However, the high $\mathrm{K}$ concentrations and $\mathrm{P}, \mathrm{K}$ and $\mathrm{Zn}$ content stood out in the stem. Live leaves showed higher $\mathrm{P}, \mathrm{K}, \mathrm{Ca}, \mathrm{Mg}, \mathrm{Cu}$ and Fe contents compared to senescent leaves. The senescent leaves stood out for the high concentrations of $\mathrm{Ca}$ and $\mathrm{Mn}$. Determining the mineral composition of stem, petiole, roots and jatropha limbo at five months of age and developed in pots containing $10 \mathrm{dm}^{3}$ of soil, Pacheco et al. (2006b) obtained variations from 0.20 to $0.34 \mathrm{dag} \mathrm{kg}^{-1}$ of $\mathrm{P}, 3.16$ to 6.94 dag kg ${ }^{-1}$ of $\mathrm{K} ; 0.69$ to $2.26 \mathrm{dag} \mathrm{kg}^{-1}$ of $\mathrm{Ca}, 0.33$ to $1.39 \mathrm{dag} \mathrm{kg}^{-1}$ of $\mathrm{Mg}$; 3.5 to $12.4 \mathrm{mg} \mathrm{kg}^{-1}$ of $\mathrm{Cu}$, 52 to $3.336 \mathrm{mg} \mathrm{kg}^{-1}$ of $\mathrm{Fe}, 118$ to $184 \mathrm{mg} \mathrm{kg}^{-1}$ of $\mathrm{Mn}$ and 25 to $121 \mathrm{mg} \mathrm{kg}^{-1}$ of $\mathrm{Zn}$.

Table 3. Dry mass, contents and contents of $\mathrm{P}, \mathrm{K}, \mathrm{Ca}, \mathrm{Mg}, \mathrm{Cu}, \mathrm{Fe}, \mathrm{Mn}$ and $\mathrm{Zn}$ in leaves, live and senescent, and in stem plants of physic nut. IFNMG, Januária campus.

\begin{tabular}{|c|c|c|c|c|c|}
\hline \multirow[t]{2}{*}{ Part } & Dry mass & $\mathrm{P}$ & K & $\mathrm{Ca}$ & $\mathrm{Mg}$ \\
\hline & g planta $^{-1}$ & \multicolumn{4}{|c|}{........................... dag kg-1. } \\
\hline Live leaves & $2.73 \mathrm{~B}$ & $0.14 \mathrm{~A}$ & $1.95 \mathrm{~B}$ & $1.77 \mathrm{~B}$ & $0.97 \mathrm{~A}$ \\
\hline Senescent leaves & $1.14 \mathrm{C}$ & $0.15 \mathrm{~A}$ & $1.85 \mathrm{~B}$ & $2.33 \mathrm{~A}$ & $1.12 \mathrm{~A}$ \\
\hline Stalk & $10.40 \mathrm{~A}$ & $0.17 \mathrm{~A}$ & $2.46 \mathrm{~A}$ & $0.52 \mathrm{C}$ & $0.36 \mathrm{~B}$ \\
\hline \multirow[t]{2}{*}{ Part } & $\mathrm{Cu}$ & $\mathrm{Fe}$ & & $\mathrm{Mn}$ & $\mathrm{Zn}$ \\
\hline & \multicolumn{5}{|c|}{ 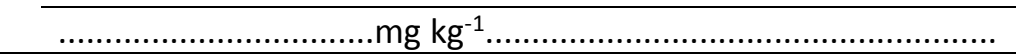 } \\
\hline Live leaves & $11.87 \mathrm{~A}$ & $652.25 \mathrm{~A}$ & & $1082.38 \mathrm{~B}$ & $34.04 \mathrm{AB}$ \\
\hline Senescent leaves & $13.15 \mathrm{~A}$ & $608.17 \mathrm{~A}$ & & $1485.42 \mathrm{~A}$ & $42.45 \mathrm{~A}$ \\
\hline Stalk & $1.50 \mathrm{~B}$ & $48.43 \mathrm{~B}$ & & $763.33 \mathrm{C}$ & $30.73 \mathrm{~B}$ \\
\hline \multirow[t]{2}{*}{ Part } & $\mathrm{P}$ & K & & $\mathrm{Ca}$ & $\mathrm{Mg}$ \\
\hline & \multicolumn{5}{|c|}{ 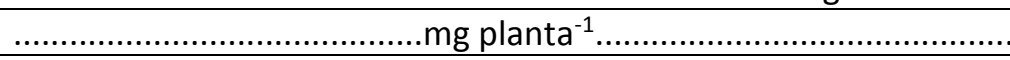 } \\
\hline Live leaves & $4.95 \mathrm{~B}$ & $51.65 \mathrm{~B}$ & & $50.93 \mathrm{~A}$ & $30.68 \mathrm{~A}$ \\
\hline Senescent leaves & $1.72 \mathrm{C}$ & $17.38 \mathrm{C}$ & & $25.67 \mathrm{~B}$ & $13.10 \mathrm{~B}$ \\
\hline Stalk & $20.91 \mathrm{~A}$ & $218.75 \mathrm{~A}$ & & $50.71 \mathrm{~A}$ & $35.72 \mathrm{~A}$ \\
\hline \multirow[t]{2}{*}{ Part } & $\mathrm{Cu}$ & $\mathrm{Fe}$ & & $\mathrm{Mn}$ & $\mathrm{Zn}$ \\
\hline & \multicolumn{5}{|c|}{  } \\
\hline Live leaves & $31.22 \mathrm{~A}$ & $1603.84 \mathrm{~A}$ & & 2477.33 B & $89.70 \mathrm{~B}$ \\
\hline Senescent leaves & $12.43 \mathrm{~B}$ & $828.59 \mathrm{~B}$ & & $1598.49 \mathrm{~B}$ & $45.66 \mathrm{~B}$ \\
\hline Stalk & $10.98 \mathrm{~B}$ & $482.74 \mathrm{~B}$ & & $7338.10 \mathrm{~A}$ & $340.11 \mathrm{~A}$ \\
\hline
\end{tabular}

*, averages followed by the same letter, in the column, do not differ significantly by the Tukey test at the $5 \%$ probability level. 
The dry mass of the aerial part of physic nut showed a quadratic response to $P$ doses and a linear response (negative effect) to physical compressions (Figure 1). The magnitude of the response to the $\mathrm{P}$ factor was much higher compared to the effect of physical compressions. The maximum production of biomass $-22.42 \mathrm{~g}$ plant $^{-1}$ - was estimated with $252.30 \mathrm{mg} \mathrm{dm}^{-3}$ of $P$ associated with the specific mass of soil equal to $1.53 \mathrm{~kg} \mathrm{dm}^{-3}$. At all doses of $P$, the production of physic nut dry matter was $2.29 \mathrm{~g} \mathrm{plant}^{-1}$ when comparing the extremes, $1.53 \mathrm{~kg} \mathrm{dm}^{-3}$ and 1.91 $\mathrm{kg} \mathrm{dm}^{-3}$, evidencing the effect negative impact of physical compression on the productive capacity of the soil.

$$
\begin{aligned}
y= & 16.44+0,1206^{* * *} P-2.39 \times 10^{-4 * *} P^{2}- \\
& 6.035^{*} \rho S R^{2}=0.9487
\end{aligned}
$$

Figure 1. Dry mass of the physic nut shoot in response to $\mathrm{P}$ doses and specific soil masses ( $\rho s$ ).

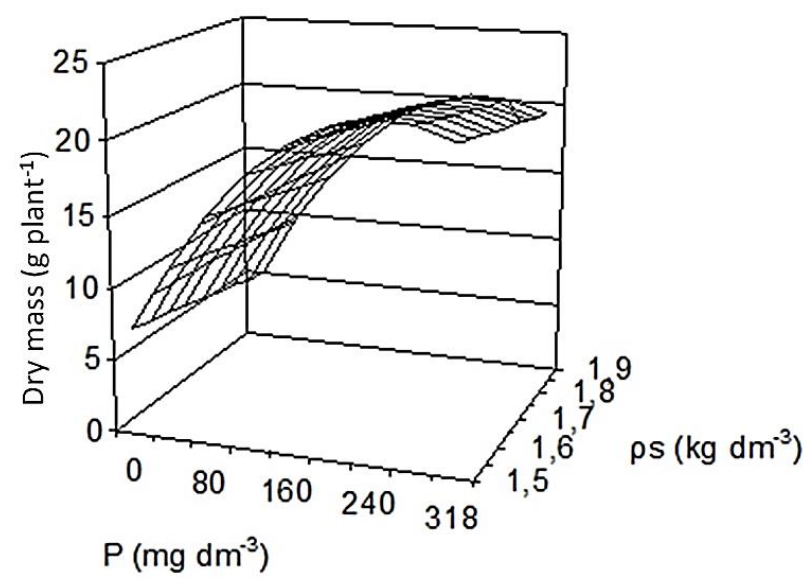

The levels of $P$ in the aerial part of physic nut showed a positive response to $P$ doses (Figure 2). The response to physical compression was negative, although its magnitude was less than the effect of phosphate fertilization. The maximum concentration of $P, 0.31 \mathrm{dag} \mathrm{kg}^{-1}$, was estimated with $318 \mathrm{mg} \mathrm{dm}^{-3}$ of $\mathrm{P}$ and specific gravity of soil equal to $1.53 \mathrm{~kg} \mathrm{dm}-3$. For young physic nut plants, grown in pots with a capacity of $15 \mathrm{dm}^{-3}$, Pacheco et al. (2006a) estimated average concentrations of $0.11 \mathrm{dag} \mathrm{kg}^{-1}$ of $P$ in the aerial part of physic nut because of the use of acidity concealer.

$$
\begin{aligned}
& y=0.27-7.22 \times 10^{-5^{*}} P+2.10 \times 10^{-6^{*}} P^{2}- \\
& 0.1009^{*} \rho s \quad R^{2}=0.9701
\end{aligned}
$$

Figure 2. $P$ content in the aerial part of physic nut in response to $P$ doses and specific soil masses ( $\rho)$.

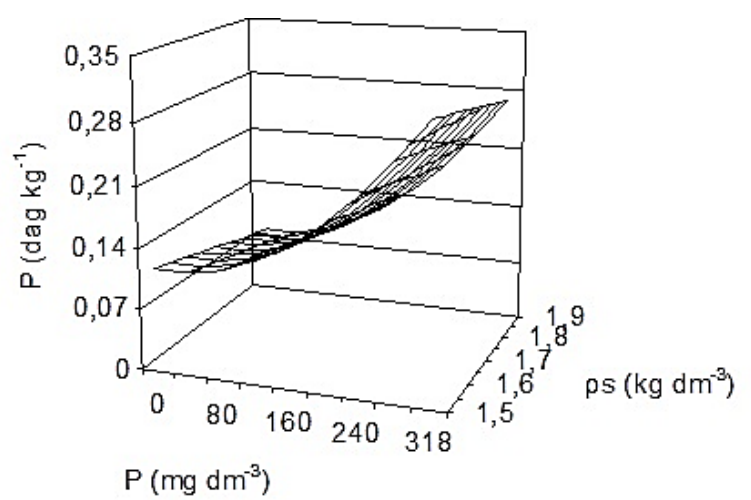

$\mathrm{K}$ concentrations responded negatively to $P$ doses and to physical compressions (Figure 3). There was a decrease of practically one unit in the concentration of $\mathrm{K}$ when comparing the worst and the best situation. K's negative response to physical compression is explained by the fact that it compromises the diffusive flow of this element when the compaction is applied to the soil, thus reducing the amounts absorbed and its consequent accumulation in the plant. The negative effect of phosphate fertilization, a process that occurred on a much larger scale, is possibly explained by the simple superphosphate source, which has $20 \% \mathrm{Ca}$, and the known competitive effect of $\mathrm{Ca}^{2+}$ on $\mathrm{K}^{+}$absorption. In this case, concomitantly with the increase in the dose of $P$, there was an increase in the availability of $\mathrm{Ca}^{2+}$ and, possibly, this when competing with $\mathrm{K}^{+}$ decreased the absorption of monovalent by the plant.

The levels of $\mathrm{Ca}$ and $\mathrm{Mg}$ showed linear responses to the doses of $\mathrm{P}$, not being significantly influenced by the compressions applied to the soil (Figure 4). The response patterns for both nutrients were very close, with $\mathrm{Ca}$ concentrations higher than $\mathrm{Mg}$ for all situations. The positive response of $\mathrm{Ca}$ to factor $\mathrm{P}$ is possibly explained by the simple superphosphate source used as phosphate fertilizer, which has $20 \% \mathrm{Ca}$ in its composition. Thus, when the dose of said fertilizer was increased, there was an increase in the availability not only of $P$, but also of $\mathrm{Ca}$, enabling a consequent greater absorption of this base.

$$
y=4.16-3.62 \times 10^{-3^{* * *}} P-0.8099^{*} \rho S R^{2}=
$$


Figure 3. $K$ content in the physic nut shoot in response to $\mathrm{P}$ doses and specific soil masses ( $\rho s)$.

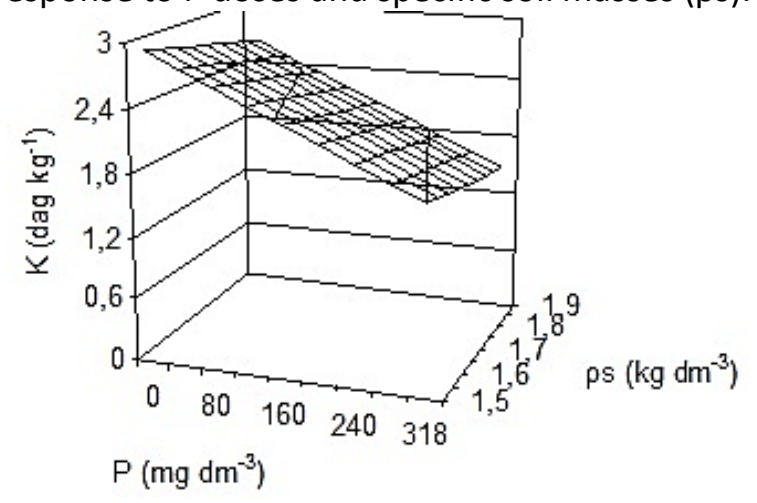

Figure 4. $\mathrm{Ca}$ and $\mathrm{Mg}$ contents in the shoot of physic nut in response to doses of $\mathrm{P}$.

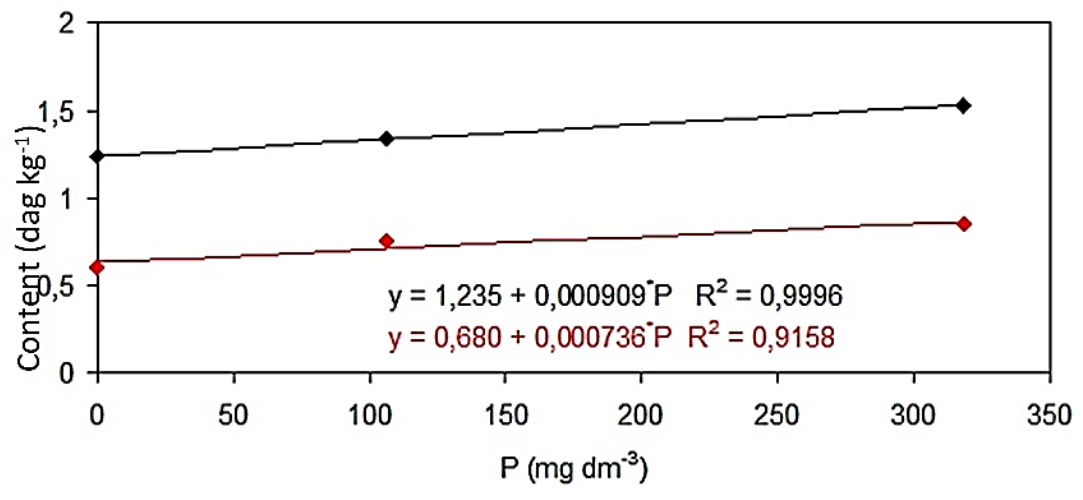

The micronutrient contents, in most situations, were not influenced by $\mathrm{P}$ doses and physical compressions (Figure 5). Only the concentration of $\mathrm{Mn}$ was significantly affected by the dose of $P$, with a decrease in this characteristic being detected with the application of phosphate fertilizer. The average contents of $4.57 \mathrm{mg} \mathrm{kg}^{-1}$ of $\mathrm{Cu} ; 32.02 \mathrm{mg} \mathrm{kg}^{-1}$ of $\mathrm{Zn} ; 209.46 \mathrm{mg}$ $\mathrm{kg}^{-1}$ of Fe were in the range detected by Pacheco et al. (2006b) when studying physic nut plants aged 5 months. In contrast, the mean concentration of $851.51 \mathrm{mg} \mathrm{kg}^{-1}$ of $\mathrm{Mn}$ differed from the range of values obtained by Pacheco et al. (2006b).

Figure 5. $\mathrm{Cu}(\bullet), \mathrm{Zn}(\bullet), \mathrm{Mn}(\bullet)$ e Fe $(\bullet)$ contents in the aerial part of physic nut in response to doses of $\mathrm{P}$.

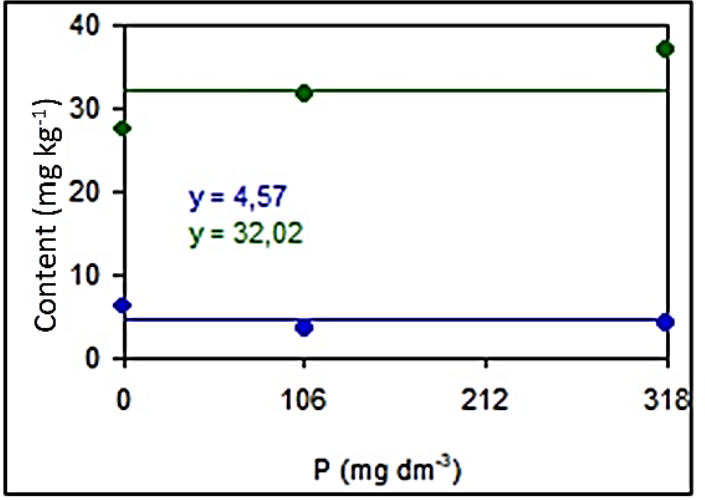

$\mathrm{P}$ and $\mathrm{K}$ contents were influenced by $\mathrm{P}$ doses and physical compressions applied to the soil, with a more pronounced response to

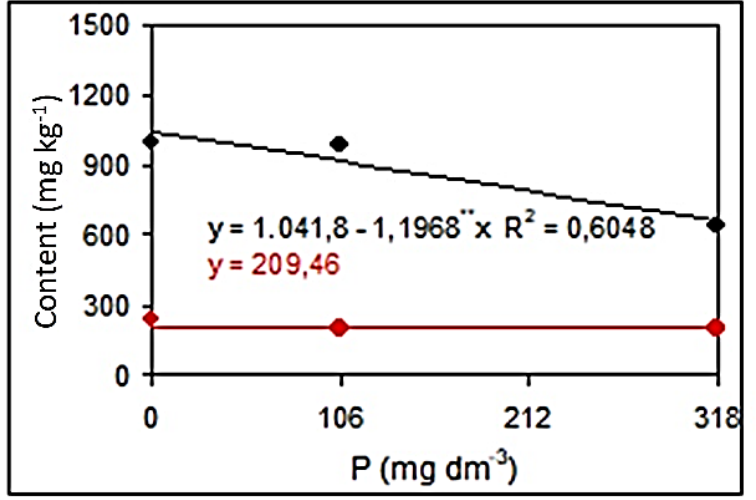

phosphate fertilization (Figures 6 and 7). The plants best nourished in $\mathrm{P}$ showed close to five times the accumulated amounts of this element 
compared to those where phosphate fertilizer was not applied.

Regarding $\mathrm{K}$, its maximum accumulation - 463.37 mg plant-1 - was estimated by applying $194.39 \mathrm{mg} \mathrm{dm}^{-3}$ of $P$ and $1.53 \mathrm{~kg} \mathrm{dm}^{-3}$ of specific mass of the soil.

$$
y=48.37-0.1681^{* * *} P-26.199^{*} \rho s \quad R^{2}=
$$

Figure 6. $P$ content in the aerial part of physic nut in response to $\mathrm{P}$ doses and physical compressions (ps).

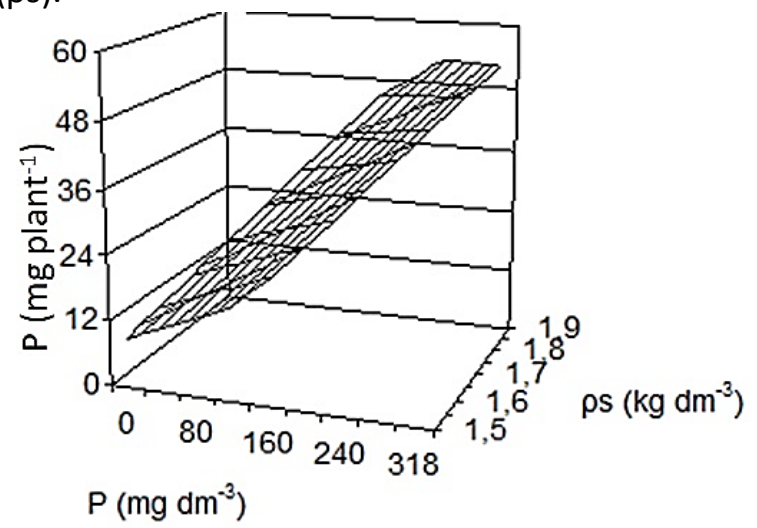

$\mathrm{y}=514.12+2.7005 * * \mathrm{P}-6.95 \times 10-3 *$

$\mathrm{P} 2-204.625 *$ ps R2 $=0.8502$
Figure 7. $\mathrm{K}$ content in the aerial part of physic nut in response to $\mathrm{P}$ doses and physical compressions (ps).

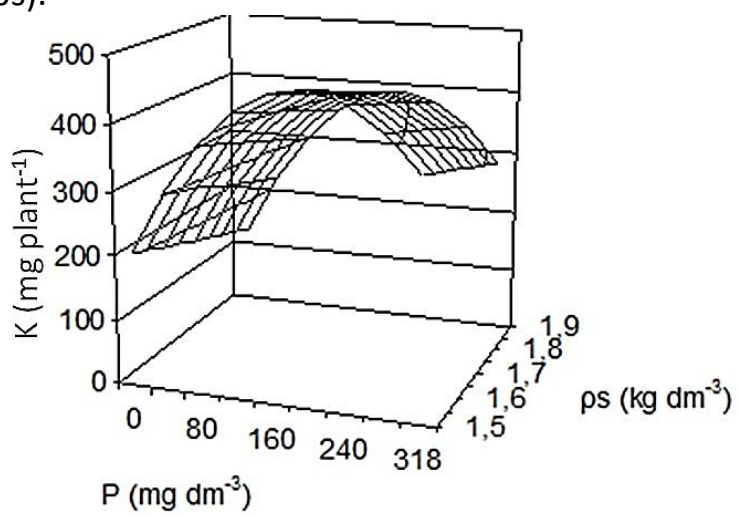

The accumulated amounts of $\mathrm{Ca}$ and $\mathrm{Mg}$ were positively influenced by the doses of $P$ (Figure 8), not being affected by the degrees of compressibility applied to the soil. Ca was practically three times more present when comparing the response of plants at doses of 0 and $308 \mathrm{mg}^{\mathrm{dmm}} \mathrm{dm}^{-3}$ of $\mathrm{P}$, and this is explained by the amount of $\mathrm{Ca}$ transmitted to physic nut using triple superphosphate. The accumulation of $\mathrm{Mg}$ followed the pattern of decreasing increments, with practically negligible gain and a tendency to fall in the highest dose of $P$, which indicates possible competition of $\mathrm{Ca}$ from phosphate fertilizer, over Mg.

Figure 8. Contents of $\mathrm{Ca}(\bullet)$ and $\mathrm{Mg}(\bullet)$ in the aerial part of physic nut in response to doses of $\mathrm{P}$.

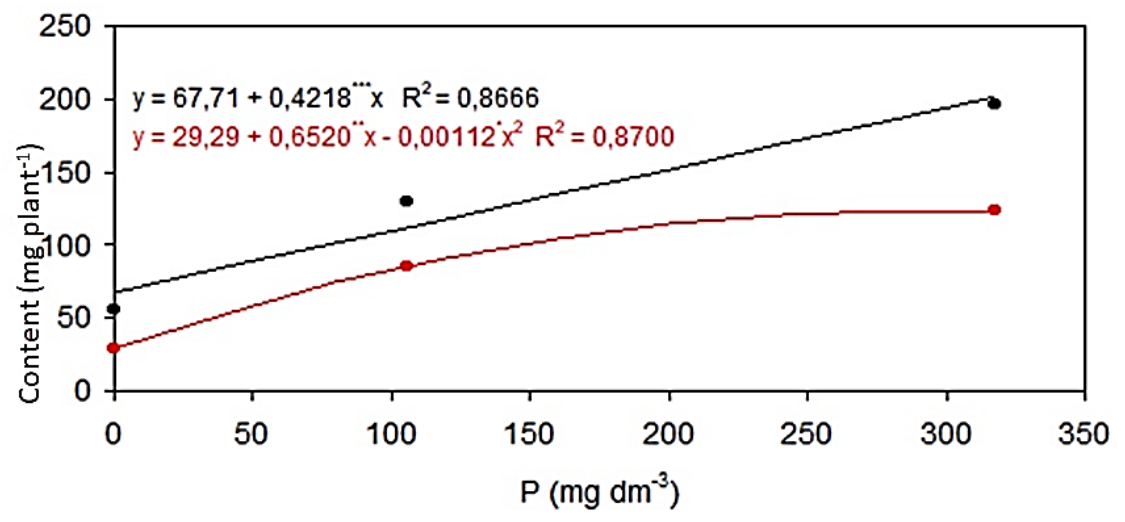

The contents of micronutrients $\mathrm{Mn}, \mathrm{Fe}$, $\mathrm{Zn}$ and $\mathrm{Cu}$ in the aerial part of physic nut were affected by $P$ doses (Figure 9). The decreasing order of accumulation was $\mathrm{Mn}>\mathrm{Fe}>\mathrm{Zn}>\mathrm{Cu}$. Pacheco et al. (2006b) obtained a different order: $\mathrm{Fe}>\mathrm{Mn}>\mathrm{Zn}>\mathrm{Cu}$, which is explained by the analysis of roots, an organ that has external contamination of adhered soil particles, which can present significant amounts of Fe from the mineral structure of the soil, thus helping to mask the correct amounts of this element in the plant. 
Figure 9. Contents of $\mathrm{Mn}(\bullet), \mathrm{Fe}(\bullet), \mathrm{Zn}(\bullet)$ and $\mathrm{Cu}(\bullet)$ in the aerial part of physic nut in response to doses of P.



\section{Conclusion}

In most situations, mineral concentrations were lower in the stem, but due to its high dry mass, this was the organ that most accumulated chemical elements, including $P$.

The concentrations and mineral content in the aerial part of physic nut showed more pronounced responses to the factor $P$ doses compared to the soil compressibility factor.

The maximum mineral content estimated in physic nut plants was $51.78 \mathrm{mg}$ of $\mathrm{P} ; 463.37 \mathrm{mg}$ of K; $201.84 \mathrm{mg}$ of $\mathrm{Ca} ; 124.18 \mathrm{mg}$ of $\mathrm{Mg} ; 76.17 \mu \mathrm{g}$ of $\mathrm{Cu} ; 4,254.07 \mu \mathrm{g}$ of Fe; $18,787.15 \mu \mathrm{g}$ of $\mathrm{Mn}$ and $769.97 \mu \mathrm{g}$ of $\mathrm{Zn}$.

\section{References}

CASTRO, J. H.; PACHECO, D. D.; SILVA, T. C.; RODRIGUES, T. M.; CRUZ, G. C. Crescimento do pinhão-manso em resposta à adubação fosfatada e à compactação de um Latossolo Vermelho Amarelo sob cultivo em ambiente protegido. Cadernos UniFOA, n. 45, p. 07-21, abr. 2021.

EMBRAPA. Centro Nacional de pesquisa de Solos. Manual de métodos de análise de solo. 2. ed. Rio de Janeiro: Embrapa, 1997. 212p.

LAVIOLA, B. G.; DIAS, L. A. S. Teor e acúmulo de nutrientes em folhas e frutos de pinhão-manso. Revista Brasileira de Ciência do Solo, v. 32, n. 5, p. 1969-1975, Oct. 2008. https://doi.org/10.1590/s0100$\underline{06832008000500018}$



MALAVOLTA, E. Manual de nutrição mineral de plantas. 1. ed. São Paulo: Agronômica Ceres, 2006. v. 1.638 p.

OLIVEIRA, E. R.; SILVA, T. C.; RAMOS, R. F. O. Evapotranspiração de referência em Januária-mg pelos métodos tanque classe " $\mathrm{A}$ " e HargreavesSamani. Colloquium Agrariae, v. 16, n. 1, p. 4854, jan. 2020. https://doi.org/10.5747/ca.2020.v16.n1.a347

PACHECO, D. D.; SATURNINO, H. M.; ALMEIDA JÚNIOR, A. B.; SOUZA, R. P. D.; ANTUNES, P. D.; RIBEIRO, D. P.; DOURADO, I. C.; PINHO, D. B. Resposta de pinhão manso à correção de acidez com cálcio e magnésio em solo de chapada da bacia do rio Jequitinhonha. In: CONGRESSO BRASILEIRO DE PLANTAS OLEAGIONSAS, ÓLEOS, GORDURAS E BIODIESEL, 3, 2006, Varginha. Resumos expandidos [...]. Biodiesel: evolução tecnológica e qualidade. Lavras: UFLA, 2006a. p. CD-ROM.

PACHECO, D. D.; SATURNINO, H. M.; MENDES, L. D.; SOARES, F. R.; PAULA, T. O. M.; PRATES, F. B. S.; SOUZA, L. C. A. Produção de massa vegetal e composição mineral de plantas de pinhão-manso. In: CONGRESSO BRASILEIRO DE PLANTAS OLEAGIONSAS, ÓLEOS, GORDURAS E BIODIESEL, 3, 2006, Varginha. Resumos expandidos [...]. Biodiesel: evolução tecnológica e qualidade. Lavras: UFLA, 2006b. p. CD- ROM.

PAULINO, J.; FOLEGATTI, M. V.; FLUMIGNAN, D. L.; ZOLIN, C. A.; BARBOZA JÚNIOR, C. R. A.; PIEDADE, S.M. DE S. Crescimento e qualidade de 
mudas de pinhão-manso produzidas em ambiente protegido. Revista Brasileira de Engenharia Agrícola e Ambiental, v.15, n.1, p.746, Jan. 2011. https://doi.org/10.1590/S141543662011000100006

SATURNINO, H. M.; PACHECO, D. D.; KAKIDA, J.; TOMINAGA, N.; GONÇALVES, N. P. Cultura do pinhão-manso (Jatropha curcas L.). Informe Agropecuário, v.26, n.229, p.44-78, 2005.

SOUZA, L. S.; BORGES, A. L.; SILVA, J. T. A. Características físicas e químicas de solos cultivados com bananeira, sob irrigação, na região Norte de Minas Gerais. Cruz das Almas: Embrapa Mandioca e Fruticultura, 1999. 24p. (Embrapa Mandioca e Fruticultura. Boletim de Pesquisa, 14).

SOUZA, Y. A.; PEREIRA, A. L.; SILVA, F. F. S.; REIS, R. C. R.; EVANGELISTA, M. R. V.; CASTRO, R. D.; DANTAS, B. F. Efeito da salinidade na germinação de sementes e no crescimento inicial de mudas de pinhão-manso. Revista Brasileira de Sementes, v.32, n.2, p.83-92. 2010. https://doi.org/10.1590/S0101-

$\underline{31222010000200010}$

VILLAR, M. L. P. Manual de interpretação de análise de plantas e solos e recomendação de adubação. Cuiabá: EMPAER-MT, 2007. 182 p. (EMPAER-MT. Série Documentos, 35). 